\title{
THE FIRST OF MAY: DO WORKERS HAVE ANYTHING TO CELEBRATE IN SOUTH AFRICA TWENTY YEARS INTO DEMOCRACY?
}

\author{
M Tenza*
}

\section{ABSTRACT}

The fight for workers' rights and other conditions of service in employment has been an on-going process for a number of decades. Unions have been at the forefront of driving this fight against stiff resistance from employers, especially prior to 1994. However, after the demise of apartheid, we have seen labour contributing immensely to the development of workers' rights in a few ways. First, the involvement of labour at the National Economic Development and Labour Council has ensured that matters affecting workers or their inputs are taken into account when Parliament legislates on issues affecting them. And, secondly, the participation of unions in the creation of collective agreements ensures that workers play a vital role in the creation of codes of conduct that regulate terms and conditions in the workplace. In areas where unions have successfully managed to address issues affecting workers these have been made known and is believed to be celebrated during the International Workers Day. The celebration of this day is not only limited to achievements or successes that unions and workers have achieved over the years, but labour can also use these kinds of celebrations to reflect on the gaps and shortfalls in their attempts to uplift the lives of workers. It is acknowledged that great improvements have been made in the area of labour law such as the proposed National Minimum Wage and

* Lecturer, School of Law, University of KwaZulu-Natal. 
various pieces of legislation and amendments to existing ones. However, it is clear that the journey of liberating workers is not near the end as unions and workers still face huge challenges of eradicating wage inequality in employment, inequality for work of equal value, the issue of safety in the workplace, labour brokering, the e-tolling system in the Gauteng roads, and many more.

Keywords: Workers day; trade unions; rights of workers; National Minimum Wage; challenges in the twenty-first century; unsafe working conditions; labour brokers; and e-tolls

\section{Introduction}

The collective power of labour (through unionism) to improve the working conditions of workers is well-documented in South Africa. Unions played a vital role during the process of liberating and reconstructing the country and in fighting for workers' rights prior to and after 1994. Unions fought for community and political rights at a time when other influential organisations and political parties were banned. As a result, the road leading to the achievement of the rights of workers enjoyed today has never been an easy one to follow for both unions and the workers they represent. Employers resisted the introduction of workers' rights in employment, which then forced workers to use collective power against them. The use of collective power in the form of strikes and protests has helped to achieve at least three broad goals for the benefits of workers in general: (1) improved wages and the creation of new rights; (2) the creation of policies aimed at improving working conditions; and (3) the achievement of political and socio-economic goals such as those dealing with the problem of e-tolls and high food prices. Trade unions have, however, gone into decline since $1994 .{ }^{1}$ Currently, they represent about twenty-five per cent of the workers and are in a crisis situation. ${ }^{2}$ This is disappointing as the journey towards liberating workers from the chains of unfair working conditions, low wages and labour brokering, is not yet complete. Bearing in mind what unions have achieved in South Africa and that they are in a state of decline the question that arises is whether the first of May (International Workers Day) is worth the celebration? This article argues that despite the decline in the appetite for trade unionism in South Africa, the tremendous contribution that unions have made in the struggle for the liberation of workers cannot go unnoticed. ${ }^{3}$ Due to a variety of achievements by trade unions this

1 See Godaan "The state of the union? Attitudes to South African trade unions" (HSRC) available at http://www.hsrc.ac.za/en/review/hsrc-review-march-2013/the-state-of-the-union.

2 Maquthu 2017: "The future of trade unions", paper presented at Annual Labour Law Conference, Emperor's Palace, Gauteng Province.

3 Most of the rights in the LRA and Constitution are the product of the hard work of unions dating back to the negotiations that gave birth to the Constitution in Kempton Park. Unions are still fighting for the rights of workers with the intent of improving their working conditions. 
article will limit its discussion to the role of trade unions in addressing the issue of inequality and discrimination in employment. The article further discusses their role in fighting for the socio-economic rights of workers.

\section{May Day: Where did it all start?}

The first of May has become International Workers Day for workers celebrating achievements in the fight for their rights and better conditions at work. ${ }^{4}$ The celebration of Workers Day began on 1 May 1886 in the United States (US). ${ }^{5}$ Prior to the declaration of 1 May as Workers Day in the United States, there was a fierce battle between employers and workers over the number of hours that workers had to work over an ordinary day. ${ }^{6}$ Previously, workers were forced to work ten to sixteen hours per day under unsafe conditions. Death and injury were common during this period in the history of labour relations. As early as 1860 , workers attempted to shorten these hours of work without any negative effect on their pay. This, however, did not materialise, due to employer resistance. It was only in the 1880 s that organised labour garnered enough strength to declare that the hours of work could be a maximum of eight hours per day. ${ }^{7}$

\section{Brief history and summary of union achievements in South Africa}

In South Africa, trade unions have played a vital role in transforming the exclusive labour relations' system that favoured a certain group of people to one where all workers are treated with fairness and dignity. ${ }^{8}$ For many years, black workers in South Africa were denied the right to form and join trade unions, to bargain collectively, and to strike. ${ }^{9}$ Certain legislation was designed to put a stop to these rights. For example, during the apartheid era, gatherings in South Africa in the form of strikes, pickets and protests, were generally regulated by the Internal Security Act. ${ }^{10}$ This Act empowered the Minister of Law and Order to prohibit the activities of any person who, in the opinion of the Minister, engaged in activities calculated to endanger the security of the state or from participating in any gathering or class of gatherings. ${ }^{11}$

4 See http://www.sahistory.org.za/dated-event/1-may-international-workers-day.

5 Idem. Fourth Annual Report, Bureau of Labour Statistics (New York, 1887) at 1.

6 Foner 1986: 8.

7 In South Africa, working hours are regulated in terms of sec 9(1) of the Basic Conditions of Employment Act 75 of 1997 (BCEA). The Act makes it clear that workers are only allowed to work eight or nine hours a day, depending on whether they work a five- or six-day week.

8 See the Preamble to the LRA.

9 SANDU v Minister of Defence (1999) 4 SA 469 (CC) par [20].

10 Act 74 of 1982.

11 Section 20 of the Internal Security Act. 
Non-compliance with the requirements of the Act could result in incarceration. The Suppression of Communism Act, ${ }^{12}$ which was later incorporated into the Internal Security Act, allowed the Minister of Justice to prohibit a gathering or an assembly whenever there was, in his/her opinion, reason to believe that the objects of communism would be furthered at such a gathering. ${ }^{13}$ The Public Safety $\mathrm{Act}^{14}$ also had an impact on the gatherings of people. It provided that the Commissioner could -for the purpose of the safety of the public - issue orders whereby any particular gathering or any gathering of a particular nature, class or kind be prohibited at any place or in any area specified in the order. ${ }^{15}$ It was only during the 1980s that the rights to form and join trade unions, to bargain collectively and to strike, were afforded to black workers. ${ }^{16}$ The coming into effect of the Constitution of the Republic of South Africa $^{17}$ (Constitution), the Labour Relations Act ${ }^{18}$ (LRA), the Basic Conditions of Employment Act $^{19}$ (BCEA), the Employment Equity Act ${ }^{20}$ (EEA) and other labour legislation, all changed the situation drastically. The Constitution provides for the labour relations' clause in section 23. This clause provides that workers have the right to "form and join a trade union, to participate in the activities and programmes of a trade union and to strike". The Constitution further provides that "(n)ational legislation may recognise union security arrangements contained in collective agreements". ${ }^{21}$ As a result, the LRA was enacted in 1995 to give effect to labour rights and other matters affecting employees and employers in employment. The LRA states that one of its purposes is to "provide a framework within which employees and their trade unions, and also employers' organisations, can collectively bargain to determine wages, terms and conditions of employment and other matters of mutual interest ...".22 A cursory review of union history in South Africa, and particularly black worker trade unionism, reveals that unions have good reasons to celebrate the role they have played in reclaiming the dignity of workers in the workplace since the dawn of democracy. ${ }^{23}$ This is supported by the number of labour rights that have been achieved through active unionism. These include, among many rights: (1) the right to freedom of association which enables workers to join or not join trade unions; ${ }^{24}$

12 Section 9 of the Suppression of Communism Act of 1950.

13 Sv Meyer 1981 (4) SA 604 (A).

14 Act 3 of 1953.

15 Regulation 7(1), Proclamation 109 issued in terms of the Public Safety Act of 1953.

16 SANDU v Minister of Defence (n 9) par [20].

17 Constitution of the Republic of South Africa, 1996.

18 Act 66 of 1995.

19 Act 75 of 1997.

20 Act 55 of 1998 .

21 Section 23(6) of the Constitution.

22 Section 1(c)(i) of the LRA.

23 Buhlungu et al 2012: 1.

24 Section 18 of the Constitution. For workers, the right to freedom of association is an enabling right which entitles them to form or join workers' organisations of their own choice, in order to promote common organisational interests. See, also, Budeli 2009: 57. 
(2) the right of pregnant employees to take maternity leave, ${ }^{25}$ and (3) the right not to be unfairly discriminated against. ${ }^{26}$ Labour also fought for the establishment of the Unemployment Insurance Fund (UIF) to cater for unforeseen circumstances that can bedevil workers, and, recently, for the National Minimum Wage (NMW) for those who earn below R3500 per month. ${ }^{27}$ All these and many other rights not listed here emphasise that unions have achieved a lot for workers in a very short space of time. ${ }^{28}$

The most important of all these labour rights is the right to freedom of association. Although freedom of association is guaranteed in the Constitution, it seems to be the foundation for all the other collective rights. For example, a strike can only be exercised by a group of people with a common goal of addressing grievances against their employer. ${ }^{29}$ Employees will be able to exercise their right to strike, picket or protest as a group only if associating themselves with that group is protected. Association in this regard includes activities of the group to whom the person is affiliated or is a member. In the absence of such liberties, it may be impossible to join or participate in the activities of an association or a union. There is, however, no provision in the Constitution and the LRA which states that the right to strike can only be exercised by a union. Practice has, thus far, shown that a strike becomes effective if it is convened by a registered union. So, it is necessary that the right to associate or not to associate with a union be protected, and hence there is a right to freedom of association in the Constitution. ${ }^{30}$

\section{How do unions participate in the creation of rights and policies affecting labour in South Africa?}

The introduction of the LRA ensured that labour plays an important role in the formulation of rights applicable to workers generally, as well as those rights that apply within a particular workplace.$^{31}$ This is done via their participation in collective agreements creating a code of conduct in the workplace. ${ }^{32}$ Some rights are created through collective bargaining up to the point where industrial action is used to break an impasse. The LRA encourages that issues affecting workers and employers must be decided by both labour and employer. It discourages unilateral decision-making

25 Section 25 of the BCEA and sec 186 of the LRA.

26 Section 9 of the Constitution, read with sec 6 of the EEA.

27 Marrian (7 Feb 2017) "Nedlac parties agree on hourly minimum wage" Business Day at 1.

28 Nearly all the labour legislation that protects worker rights was enacted immediately after 1994. This includes the Basic Conditions of Employment Act of 1997, the Compensation for Occupational Injuries and Diseases Act 130 of 1993, the Skills Development Act 97 of 1998, and the Mine Health and Safety Act 29 of 1996.

29 Section 213 of the LRA.

30 Section 18 of the Constitution.

31 See Preamble to the LRA.

32 Section $1(1)(c)$ and (d) of the LRA. 
as it emphasises mutual understanding on matters affecting both parties. The role of trade unions in advancing workers' rights is not only limited to the creation of codes of conduct and collective agreements in the workplaces where they enjoy a certain representation (eg majority representation). Unions also participate in the formulation of policies regulating or affecting labour, and recommend to parliament on the way forward or reject a proposal where they are of the view that it would not advance the interest of workers. This they do via participation at the National Economic Development and Labour Council (NEDLAC). It is a representative, specialist and state-funded body created out of the realisation that labour legislation is unique and requires a collaborative tripartite initiative. ${ }^{33}$ NEDLAC provides a platform where interaction between the State, organised labour and organised business takes place. This interaction is important for ensuring that all role-players are involved in policymaking and envisaged legislation that could have an impact on employers and employees. ${ }^{34}$ The ultimate aim is to make economic decisions more inclusive, and to promote the goals of economic growth and social equity. Before a labour matter goes to Parliament, it needs to be referred to NEDLAC.

NEDLAC's work is conducted in four chambers, which discuss different aspects of social and economic policy. The chamber tasked with all new labour law and changes to existing law is the Labour Market Chamber. A proposal to amend the LRA to include a provision that will enable victims to claim directly from a union for strike-related violence, will have to go via NEDLAC. It will have to be discussed at NEDLAC with some proposal for Parliament to consider when a Bill is eventually tabled. NEDLAC has, however, been criticised for wasting time in its deliberations and because of the inability of parties to reach consensus on recommendations. ${ }^{35}$ The reasons for the latter, are that representatives from government and labour are not mandated by their principals to take decisions, and not all parties are represented at NEDLAC. According to some authors NEDLAC is at a "tipping point" since it has become less effective and more adversarial in recent years. ${ }^{36}$

\section{The road ahead and challenges facing labour in the twenty-first century}

Despite having the right to freedom of association and other collective rights as "weapons" in the fight against abuse and to promote better working conditions in the workplace, workers and their unions still face challenges in navigating their way forward and addressing issues affecting workers in general. Some of these challenges date back to the pre-1994 era, and are not yet addressed twenty-three years into

33 Parsons 2001: 240; and, also, Parsons 2007: 124.

34 Section 5 of the National Economic Development and Labour Council Act 35 of 1994.

35 Gostner et al 1998: 137; and Webster 1995: 39.

36 Smith 2014: 81. 
democracy. These include the issues of inequality in employment, unemployment, poverty, and unsafe working conditions particularly in the mining sector. These issues have been on the list of grievances against employers, but it seems there is lack of willingness from the side of employers to deal with them decisively. Unions would be failing workers if these challenges were not taken seriously and addressed.

Due to the number of challenges facing workers, this articles investigates the role of trade unions in addressing wage inequality, labour brokers and unsafe working conditions, and particularly in the mining sector.

\section{The issue of wage inequality}

The Constitution recognises that the history of South Africa was characterised by racial discrimination and accompanying injustice. ${ }^{37}$ As a result, the Constitution speaks directly to issues of inequality and unfair discrimination, and provides the people of South Africa with an equality clause to heal such injustices. ${ }^{38}$ The equality clause provides that "everyone is equal before the law and has the right to equal protection and benefit of the law". ${ }^{39}$ It is not only racial inequality that has been outlawed, but also all other forms of unjustified inequality, including wage inequality or discrimination.

By implication, the drafters of the Constitution and the equality clause, in particular, had in mind a system of using law to address issues of inequality. To confirm its commitment to this, the legislature enacted the Employment Equity Act ${ }^{40}$ (EEA) to deal specifically with discrimination and inequality in employment. The issue of equal treatment and the elimination of unfair discrimination is also the subject of debate at international level. There are two important conventions dedicated to addressing inequality and unfair discrimination among member states. These are the International Labour Organisation (ILO) Equal Remuneration Convention 100 of 1951, which South Africa ratified in 2000, and the ILO Discrimination (Employment and Occupation) Convention 111 of 1958, which was ratified in 1997. These international treaties place duties on member states to comply with their provisions and to reflect an international position on a particular subject. In addition, South Africa is a signatory to the Southern African Development Community (SADC) Protocol on Gender and Development of 2008. The Protocol requires member states to ensure the application of the principle of equal pay for work of equal value to both males and females. It further suggests that member states should review, adopt and implement legislative measures to achieve these goals. ${ }^{41}$

38 Ibid.

39 Section 9(1) of the Constitution.

40 Act 55 of 1998.

41 Article 19(2)(a) of the Protocol. 
However, despite the initiatives by South Africa to comply with the above international conventions, and having enacted legislation to deal specifically with these issues, there has been criticism of the failure to include a specific provision in the EEA that deals specifically with the issue of equal pay, and this is thus a sign of a failure to comply with international law. ${ }^{42}$ Case law has also confirmed this position. In Mangena v Fila South Africa (Pty) Ltd, ${ }^{43}$ the applicant, a black male, alleged that the respondent had discriminated against him on the grounds of race, in that it paid his chosen comparator, a white female, a higher salary despite the fact that the work performed by both of them was the same or alternatively of equal value. The Labour Court remarked that the EEA does not specifically regulate equal pay claims, as is the position with equality legislation in many jurisdictions. It further remarked that a claim for equal pay for work of equal value should be determined in terms of the EEA, as the Act is broad enough to incorporate such a claim. ${ }^{44}$

The legislature has, however, responded to accusations of failure to comply with international law by introducing the Employment Equity Amendment Act ${ }^{45}$ (EEAA), which amends the EEA. ${ }^{46}$ The EEAA makes specific provisions to address the issue of "equal pay for work of equal value" and attempts to eradicate inequality with regard to the performance of work of equal value. ${ }^{47}$ It prohibits unfair discrimination in the terms and conditions of employment between employees performing the same or substantially the same work or work of equal value. ${ }^{48}$ The EEAA further provides that the Minister may prescribe the criteria and methodology for assessing work of equal value. ${ }^{49}$ As a follow-up to these requirements, the Minister has, thus far, published the Employment Equity Regulations of 2014. ${ }^{50}$ These Regulations set out factors which should be used to evaluate whether two different jobs are of equal value. These factors are:

(a) the responsibility demanded of the work, including responsibility for people, finances and material;

(b) The skills, qualifications, including prior learning and experience required to perform the work, whether formal or informal;

(c) Physical, mental and emotional efforts required to perform the work; and

42 Commission for Employment Equity in respect of opportunity and treatment, in Commission for Employment Equity Annual Report 3; clause 333 of the Memorandum on Objects of Employment Equity Amendment Bill 2012, as found in the Employment Equity Amendment Bill [B31B of 2012]. See Ebrahim 2016: 1.

43 (2010) 31 ILJ 660 (LC).

$44 \quad$ Idem at 668.

45 Act 47 of 2013.

46 Act 55 of 1998.

47 Section 6(4)-(5) of the LRA as amended.

48 Ibid.

49 Ibid.

50 See Government Gazette No 37873 of 1 Aug 2014. 
(d) To the extent that it is relevant, the conditions under which work is performed, including physical environment, psychological conditions, time when and geographic location where the work is performed. ${ }^{51}$

In Louw v Golden Arrow Bus Services (Pty) $L t d,{ }^{52}$ the applicant, a black male employed as a buyer alleged that the respondent/employer committed direct unfair discrimination on the ground of race, in that it paid his comparator, a white male employed as warehouse supervisor, a higher salary for work of equal value. The Labour Court held that the mere differential treatment of persons from different races was not per se discriminatory on the grounds of race, unless the difference in race was the reason for the disparate treatment. The court further found that the applicant had failed to prove that the jobs, on an objective evaluation, were of equal value..$^{53}$ However, it is not only important to have legislation that addresses issues of equal pay for work of equal value, it is also important that workers are given decent work that will enable them to live a better life or attain a living wage. ${ }^{54}$ One of the goals of the ILO is the achievement of "decent" and "productive" work for both men and women in conditions of freedom and equity, security and human dignity. ${ }^{55}$ The understanding of the concept "decent work", is that work is not only a source of income but also a measure of determining one's dignity and also a source of family stability, peace in the community and economic growth. ${ }^{56}$ To further the goal of "decent work", the ILO's Decent Work Agenda ${ }^{57}$ aims to implement decent work at country level, by means of policy and institutional interventions and the Decent Work Country Programmes that have been developed to identify decent work deficits in member countries, and also to devise strategies and targets to overcome such deficits. ${ }^{58}$ In support of this, South Africa has pledged its commitment to the attainment of decent work and sustainable livelihoods for all workers. ${ }^{59}$ The question that then arises, is whether it is possible to implement these ILO provisions in certain sectors of the economy such as agriculture, domestic sector and hospitality industry, for example? It is argued that in South Africa there have been several interventions to uplift the plight of employees in these sectors. For example, the Minister of Labour often makes sectoral determinations with regard to wages in these sectors, as well as other sectors identified by the Economic Conditions Commission (ECC) as worthy of intervention. These determinations are, however, insufficient to cater for

51 See Government Gazette No 37873 of 1 Aug 2014.

52 (2000) 21 ILJ 188 (LC).

53 Idem at 197.

54 Equality is at the heart of the notion of decent work, see Hepple 2001: 5.

55 ILO 1999.

56 ILO 2010.

57 Decent Work Agenda of the ILO, available at http://www.ilo.org/global/about-the-ilo/decentwork-agenda/lang-en/index.htm.

58 ILO [unknown date].

59 Cohen and Moodley 2012: 329. 
an acceptable living wage for such employees. It can therefore be argued that such determinations do not bring about a living wage for these workers. For example, the current wage determination in domestic workers is R12.42 or R11.91 per hour, depending on whether a person works in rural or urban areas. ${ }^{60}$ This is short of the proposed National Minimum Wage of R20 per hour. It is, however, expected that these hourly rates will be pushed up when the NMW commences.

The absence of a living wage for workers in the domestic and other sectors such as the taxi industry is always a concern to many people, as it not only affects their standard of living, but also their dignity. ${ }^{61}$ Furthermore, gender inequalities continue to undermine the project of eradicating inequality and discrimination based on payment: the so-called payment for equal work of equal value. For example, women face glaring pay differentials, gender stereotyping, discrimination based on maternity and family responsibilities, and difficulties in balancing work and family life. ${ }^{62}$ Women are mainly concentrated in the feminised professions like nursing and teaching (which is horizontal occupational segregation), while also remaining in lower job categories compared to their male counterparts and being grossly underrepresented in senior positions. ${ }^{63}$ They are also paid less compared to their male counterparts. Despite commitment by the South African government to decent work and security for all workers ${ }^{64}$ the general sense is that there are quite a large number of vulnerable workers in South Africa with those working on farms earning pitiful wages below the prescribed minimum wage. The grey literature has also reported on these matters. For example, in the wake of the wage strike in the farming industry in De Doorns in the Western Cape Province, the Minister of Labour intervened and announced a minimum wage of R105 per day for all workers in the farms. ${ }^{65}$ Despite this announcement by the Minister, certain farmers still pay their workers less than the prescribed minimum wage. ${ }^{66}$ In People's Union for Democratic Rights $v$ Union of India, ${ }^{67}$ workers were paid wages lower than the prescribed minimum wage contrary to various pieces of legislation regulating the industry. The matter was referred to the Supreme Court of India. The Court, in concluding that any work done for less than the minimum wage amounts to forced labour, stated that:

60 A domestic worker is defined as including housekeepers, nannies, domestic drivers and gardeners.

61 Section 10 of the Constitution.

62 Cohen and Moodley 2012: 325.

63 Idem at 323.

64 See Decent Work Agenda of the ILO.

65 Government Gazette No 36115 of 5 Feb 2013.

66 Mtyala "Western Cape Farmers Pay above Minimum" Sowetan Live, available at http://www. sowetanlive.co.za/news/2013/02/25/western-cape-farm-pay-above-minimum (accessed 22 Feb 2017).

$67 \quad 1983(1)$ SCR 546 at 491. 
[I]t may be physical force which compels a person to provide labour or service to another or it may even be compulsion arising from hunger or poverty, want and destitution. Any factor which deprives a person of a choice of alternatives and compels him to adopt a particular course may properly be regarded as 'force' and if labour or service is compelled as a result of such 'force' it would be 'forced labour'. ${ }^{6} 8$

Around 6.6 million working people in South Africa are paid less than R20 per hour. ${ }^{69}$ This implies that such employees live or earn below the breadline. ${ }^{70}$ The most affected workers are domestic workers, taxi drivers, and those in the private security industry, hospitality, agriculture, forestry, wholesale and retail, meat trade, fishing, textile, clothing, hairdressing, furniture and cleaning industries as these workers are known to be paid less than what other sectors pay. It is furthermore not only employees employed in these sectors that are affected by the scourge of wage inequalities since there is a general sense of wage inequality in South Africa, with black workers being paid less relative to their white counterparts doing the same job. ${ }^{71}$

\section{Addressing wage inequality and the proposed minimum wage}

Although inequality and unfair discrimination is contrary to the law, the main problem is the resultant poverty. ${ }^{72}$ The dominant feature of South Africa's equality jurisprudence is income inequality and the resultant poverty which affects most of the population. To deal with these challenges, the Constitution makes provision for a regulatory framework for substantive equality and for redressing unfair discrimination in employment. ${ }^{73}$ As stated above, in order to give content to the equality provision of the Constitution, the EEA was enacted to deal specifically with these issues in employment. In this regard, the EEA can be described as transformative legislation that is intended to reduce both social and economic disparities between groups, and to transform the hearts and minds of South Africans. ${ }^{74}$

In addition, the EEA, as amended in 2014, expands on the principle of equal pay for work of equal value. Section 6(4) of the amending Act provides that "a difference in terms and conditions of employment between employees of the same employer

68 Ibid.

69 Voladia "How the search for a new minimum wage laid bare South Africa's fault lines" Mail \& Guardian, available at http://mg.co.za/article/2016-11-28-how-the-search-for-a-nationalminimum-wage-laid-bare-south-africas-faultlines/ (accessed $22 \mathrm{Feb} 2017$ ).

70 See https://www.buildon.org/global-education-crisis-facts/?gclid=Cj0KCQjw95vPBRDVARIsA KvPd3LUbOcUfpwsRWJK-wXnd5rQXN62rYHoELR3pd7obrZnnKTGoCwBsJIaAmJ1EALw_ $w c B$ (accessed 18 Oct 2017).

71 Louw v Golden Arrow Bus Services (n 52); and Magma v Fila South Africa (Pty) Ltd.

72 Tenza (26-28 May 2015) "A marathon of twenty years of eradicating poverty: Is South Africa making progress?", Proceedings of $2^{\text {nd }}$ International Conference on National Capacity Building Strategy for Sustainable Development and Poverty Alleviation, Dubai.

73 Section 9 of the Constitution.

74 Kok 2008: 124-125. See, also, Cohen 2012: 35. 
performing the same work, or work of equal value, is unfair discrimination if the difference is directly or indirectly based on any one or more of the grounds listed in section 6(1) of the EEA".

It is therefore submitted that since the economy is failing to create jobs, more focus should be directed at addressing income poverty, that is, paying more attention to people who are already working and ensuring they have secured employment and earn decent wages. ${ }^{75}$ To achieve this, the concept of decent work will have to be harnessed to address inequality in the workplace, and a paradigm in terms of which rights that currently apply to labour relationship will extend to all forms of work. As stated above, most of the people who work in domestic, retail, agriculture and other sectors support big families and are usually breadwinners in their homes. In this regard, those who are fortunate to be employed or to be working, need to be targeted as a strategy to enhance their standard of living and, eventually, that of the families they support. This will take place through a radical elimination of income inequality for people who are employed in sectors known to be paying low wages, that is, below the poverty line.

The proposed NMW seems to be the solution to the problem of inequality and low wages, with its ambition of compelling employers to pay employees at least R20 per hour which translates into R3500 a month. ${ }^{76}$ The government has led the way in terms of attempting to address this issue. It has proposed legislative reforms to be introduced into our labour relations' system. The parties at NEDLAC have agreed on this minimum wage, and it is expected to apply across all sectors in the Republic. ${ }^{77}$ Employers are expected to comply, unless exempted in terms of the law. A number of workers are expected to benefit from this initiative. The introduction of the NMW is sourced from international law. The ILO Minimum Wage Fixing Convention of 1970 obliges member states to establish a system in their municipal law or domestic law that will introduce a minimum wage covering all groups of wage earners, whose terms of employment are such that coverage would be appropriate.$^{78}$ However, South Africa has not yet signed the Convention. The introduction of a minimum wage is not unique to South Africa, as other countries such as the United Kingdom, China, Malaysia and the Cape Verde Islands all have a minimum wage policy. NEDLAC also agreed on the establishment of a National Minimum Wage Commission (NMWC) to review the minimum wage annually.

75 This does not mean that the unemployed are not catered for, but that government should keep formulating polices that will open avenues for the unemployed.

76 A minimum wage is the lowest hourly, daily or monthly wage that employers may legally pay employees or workers.

77 Godongwana (30 Aug 2015) "Essential steps towards a renewal of SA's economy" Sunday Times at 19.

78 Article 1 of the Minimum Wage Fixing Convention of 1970. 
There is criticism that the introduction of the NMW will result in job losses, increased unemployment, and low economic growth. ${ }^{79}$ Research has rejected this view as lacking empirical evidence. ${ }^{80}$ It can also be argued that if the NMW is set too high, the government would be running the risk of poor compliance and difficulty in enforcing compliance with the system. For example, farm workers in Cape Town still earn low wages even after the determination by the Minister of Labour. It can also be argued that the minimum wage is far from a living wage and can hardly address poverty. The Congress of South African Trade Unions (COSATU) has lambasted it saying that it lacks definite targets. Their argument further states that the yet to be formed NMWC will review the minimum wage annually, which, according to COSATU, leaves the door open for a zero increase if a yet-to-be formed NMWC decides not to recommend an increase. ${ }^{81}$ The government, however, has responded to the criticisms of the NMW by saying that this is a significant starting point leading to the achievement of the goal of a living wage, which is broadly understood to be the amount needed for a household to achieve a decent standard of living. ${ }^{82}$ The impact of the NMW on poverty will be monitored through the NMWC. It is believed that the NMWC will have more powers to deal effectively with those employers who fail to comply with the law. In addition, labour inspectors need to be reskilled to enable them to perform their obligation satisfactorily.

It is further argued that the NMW will, in the long run, lead to job losses as those employers who cannot afford the minimum wage will opt to implement retrenchment in order to meet the legislative or other demands. To cater for these eventualities, exemptions are provided to employers who cannot afford to pay their employees the prescribed minimum wage..$^{83}$ This is not automatic, and the affected employers should apply for exemptions so that these developments do not affect them negatively. Exemption is, however, not indefinite as it is only applicable until $2019 .{ }^{84}$ This means that after 2019 , all employers are expected to comply with the law and pay their employees the prescribed minimum wage. ${ }^{85}$

The main aim of the minimum wage is the alleviation of poverty among vulnerable people in South Africa by bridging the wage gap, including between gender, and thereby overcoming poverty. To determine if the minimum wage achieves the desired goals, it will have to be assessed against levels of poverty. If implemented properly, the NMW will not only have a positive effect on individual workers and

79 Belman and Nawakitphaitoon 2015: 621.

80 Ibid.

81 Ensor "Minimum wage to come into force in May 2018" (accessed 19 Oct 2017) available at http://www.heraldlive.co.za/news/2017/02/08/minimum-wage-come-force-may-2018/.

82 Ibid.

83 See the National Minimum Wage Report (accessed 19 Oct 2017) available at http://www.treasury. gov.za/publications/other/NMW\%20Report\%20Draft\%20CoP\%20FINAL.PDF.

84 See NMW Report, (accessed $21 \mathrm{Jul} 2017$ ) available at http://www.treasury.gov.za/publications/ other/NMW\%20Report\%20Draft\%20CoP\%20FINAL.PDF.

Ibid. 
their families, but will also deliver broader economic and social benefits. If set at an appropriate level, the NMW could help stimulate the economy, while also reducing poverty and inequality.

The implementation of the NMW was expected to take effect on 1 May 2018, and the government was tasked with accelerating the process of initiating legislation to regulate this matter. ${ }^{86}$ This means that the government was tasked with rolling-out the Minimum Wage Bill and amendments to the BCEA for the minimum wage to be available and implemented by May 2018. The BCEA will have to be amended to ensure that it provides for the minimum wage bill. However, some low-income workers such as farmworkers and domestic workers will be excluded from the application of the NMW as there is a sectoral determination that applies to such sectors. It is however, believed that domestic and farmworkers will get at least R18 an hour, while R15 per hour will be paid to domestic workers and R11 an hour for people employed in the government's expanded public works programme. NEDLAC has agreed that the farm, forestry and domestic sectors will be brought up to 100 per cent of the minimum wage within two years pending research by the NMWC. ${ }^{87}$

\section{The issue of labour broking}

Labour broking entails that one person supplies the business of his or her client with workers. It is a well-known form of exploitation of workers earning low wages who at the same time share their small wages with labour brokers. In South Africa, the system of labour brokers has been in existence for quite a number of years, but without a solution. ${ }^{88}$ Labour broking has been a burning issue in South Africa's employment sector with many workers employed through this system complaining that the system parasitises them.

The system of labour broking is referred to as Temporary Employment Services (TES), and is regulated by section 198 of the LRA as amended by section 198A of the Labour Relations Amendment Act. ${ }^{89}$ TES is defined as "any person who, for a reward, procures for or provides to a client other persons who render services to, or perform work for, the client; and who are remunerated by the temporary employment service". ${ }^{90}$

Labour broking or the externalisation of labour, as it is commonly referred to in academic circles, is a method of providing labour that is triangular (or trilateral) in which a client or core business implicitly or explicitly determines the conditions under which the employees of the service provider engages work. ${ }^{91}$ According

86 Marrian N "Nedlac parties agree on hourly minimum wage" Business Day (7 Feb 2017) at 1.

87 The Times 3 Nov 2017 at 8.

88 Van Niekerk et al 2015: 68.

89 Act 6 of 2014.

90 Section 198 of the LRA.

91 See Theron 2014: 1831. 
to Benjamin, triangular relationships exist where the recruitment, dismissal and employment functions conventionally performed by the employer, are outsourced to an intermediary (or a TES).$^{92}$ With this triangular relationship, the TES is responsible for the recruitment, employment and placement of workers. The client, on the other hand - who happens to be an employer - issues instructions and supervises the worker in his/her her workplace, without incurring the responsibility of an employer. Thus it is clear that the reason for externalisation of work to labour brokers is to avoid the application of labour law. ${ }^{93}$ The end result is that workers are deprived of labour-law protection.

Angered by this triangular employment relationship and the consequences of being employed via the labour broker, workers have been complaining that the existence of a middle-man (broker) between the employee and employer causes great hardship in terms of their survival as they share the small wage they earn with the labour broker. An example of this dissatisfaction is found in the platinum mines, where, more than other mining sectors, they have externalised employment and rely largely on agencies and contractors to complement a relatively small "core" workforce. ${ }^{94}$ It is therefore not coincidental that there were increases in the number of violent strikes in the platinum mines in 2012 and early 2013.

\section{The regulation of labour brokers}

With the introduction of the new amendments in the Labour Relations Amendment $\mathrm{Act}^{95}$ (LRAA), the fight against the casualisation of workers has taken another turn in favour of workers. ${ }^{96}$ The coming into effect of the LRAA has significantly improved the position of workers supplied by labour brokers in South Africa. First, it provides that the client of the labour broker or the person or business being supplied with workers by the labour broker, is the employer of the labour-broker staff. ${ }^{97}$ Second, employers or clients of labour brokers now have a certain responsibility towards employees - something they never had before. For example, during dismissal disputes, claims that were usually the sole responsibility of a labour broker are now a shared responsibility between the labour broker and the client employer. ${ }^{98}$ Third,

92 Benjamin 2010: 847. See, also, Theron 2005: 618-649, who mentions that the origin of this phrase remains a mystery.

93 Benjamin P "Workers' protection in an increasingly informalised labour market: The case of South Africa", paper presented at the workshop 'Decent work agenda for South Africa', Cape Town, South Africa, April 2007.

94 Theron 2014: 1832.

95 Act 6 of 2014

96 Section 198A(1) of the LRA as amended by the LRAA.

97 Section 198A(3) of the LRA as amended by the LRAA.

98 Ibid. 
employers are now compelled to employ full-time employees who have been in their employ for more than three months in succession. ${ }^{99}$

Another important change that the amendments brought to the terrain of labour relations, is that for a period of three months, the labour broker can hold onto the status quo - that is, be the employer of the workers procured to provide services to the client employer. After three months, the amendments state that the worker provided by the labour broker is deemed to be an employee of the client employer. ${ }^{100}$ This is, however, not a solution, as employers have a flexible staff complement which they can use to justify the use of labour brokers. A permanent solution is required, where there is in fact a total ban on labour brokers. If labour brokers can hire workers only up to three months, employers will rotate workers to suit their needs or to avoid the application of the relevant law.

\section{Unsafe working conditions}

The issue of safety in the workplace has been on the negotiating table whenever unions and employers negotiate terms and conditions of work. This is particularly the case in the mining sector. Before 1994, the mining industry would report about 500 fatalities annually. However, this figure has dropped substantially from where it was prior to 1994. In 2016, the Chamber of Mines reported seventy-three deaths down from seventy-seven in 2015. ${ }^{101}$ Despite this decline, unions have been arguing that there is no commitment by employers to prevent or avoid accidents in the mines, caused by rock falls and other factors. An example is the Lilly Gold Mine incident where three employees have been trapped underground for almost three years with no attempts undertaken to recover the bodies. The question is whether unions are doing enough to compel or persuade employers to deal effectively with these kinds of accidents.

\section{Training and compliance with applicable legislation as preventative measures}

There is a general duty on employers to provide employees with a safe working environment. In terms of the Occupational Health and Safety Act ${ }^{102}$ (OHSA), an employer must provide for the health and safety of persons at work and in connection with the use of plant and machinery protection against hazards to health and safety arising from the activities of people at work, and also for the establishment of an Advisory Council. ${ }^{103}$ In terms of OHSA, every employer must provide and maintain

99 Section 198A(3) of the LRA as amended.

100 Section 198B(3) of the LRA as amended.

101 Mtongana M (12 Feb 2017) “Mine bosses warn on 'sledgehammer' safety inspections" Business Times at 7.

102 Act 85 of 1993.

103 Preamble to the OHSA. See, also, s 1 of MHSA. 
a safe working environment. The employer must provide and maintain all the equipment necessary to do the work and all the systems in terms of which work is done. This must be in a condition that does not adversely affect the health and safety of employees. ${ }^{104}$ Before using personal protective equipment, the employer must try and reduce or remove the danger. Only after this has been attempted, should personal protective equipment be used. In terms of the Mine Health and Safety Act ${ }^{105}$ (MHSA), there is a duty on the employer and employees to create a culture of health and safety and also a duty to enforce safety measures. ${ }^{106}$ Some of these duties include the need to maintain a working environment that is safe and without risk to the health of employees, ${ }^{107}$ and to ensure that people who are not employees, but who may be affected during the operation, are informed of the potential damage or harm. ${ }^{108}$

To ensure that all the above obligations are met, the employer must ensure that every employee is informed about hazards to his or her health, the safety attached to any work that must be performed, and the precautionary measures that must apply in respect of the hazards while every employee is expected to take all reasonable steps to ensure their own safety and that of others. ${ }^{109}$ However, it would be a fruitless exercise to expect employees to do all of the above if they do not have training on how to use equipment and how to protect themselves from unforeseen hazards in their workstations, and particularly in the mining industry where accidents often occur. Because of unique dangers in the mining sector, workers there need extensive and on-going training. Such training must be compulsory in order to ensure that all involved are aware of the needed reactions should a danger takes place. Each time a new job is assigned to an employee or a new employee is employed, training must be provided. The training must also include courses on the use of new technology if the mine plans to use such technology in its operations.

Training will also not be sufficient if the mine does not prioritise safety. At all times, employees need to be reminded that safety is of the utmost importance. The union has the task of ensuring that all that the legislation and collective agreement promises are fulfilled. It is also their duty to ensure that there are no deaths and injuries in the mining and other sectors. Unions should take initiatives on this and monitor compliance by both employers and employees.

104 Section 8(2) of the OHSA.

105 Act 29 of 1996.

106 Section 1 of the MHSA.

107 Section 5(1) of the MHSA.

108 Section 5(2)(b) of the MHSA.

109 Section 13 of the OHSA. 


\section{Conclusion}

Evidence shows that the participation of labour in the creation of labour rights and their involvement at NEDLAC is bearing some fruit. Workers have managed to secure many labour rights that enable them to achieve the dream of favourable working conditions, to bargain collectively with employers using negotiating platforms provided by the law to secure wages at the negotiating table, and have rights to take industrial action to press for their demands. Other rights available to employees include the right to freedom of association which includes the right to form or join a union of your choice, the right to assembly, the right to picket, and the right to strike. However, the struggle for better conditions of work, wage increases, and all other issues that affect workers in and outside their workplaces is not yet complete. The declaration of the first of May as International Workers Day seems to remind workers in South Africa that regardless of the milestones they have travelled thus far in terms of fighting for and addressing the plight of workers, there is much that needs to be done in the future. Even though workers have achieved the MNW which is, in fact, regarded as inadequate due to high inflation in South Africa, they still need to work hard to address issues of inequality, in particular, and equal pay for work of equal value, labour brokers, e-tolls, and unsafe working conditions, which still prevail in many workplaces.

\section{BIBLIOGRAPHY}

Belman D, Wolfson P \& Nawakitphaitoon K (2015) "Who is affected by the minimum wage?" Industrial Relations: J of Economy and Society 54(4): 582-621

Benjamin P (2010) "Decent work and non-standard employees: Options for legislative reform in South Africa: A discussion document" Industrial Law Journal 31: 845-871

Budeli M (2009) "Workers right to freedom of association and trade unionism in South Africa: An historical perspective" Fundamina: A Journal of Legal History 15(2): 57-74

Buhlungu S \& Tshoaedi M (2012) COSATU Contested Legacy (Cape Town)

Cohen T \& Moodley L (2012) “Achieving decent work in South Africa” Potchefstroom Electronic Law Journal 15(2): 320-344

Cohen T (2012) "The efficacy of international standards in countering gender inequality in the workplace" Industrial Law Journal 33: 19-35

Ebrahim S (2016) "Equal pay for work of equal value in terms of the Employment Equity Act 55 of 1998: Lessons from the International Labour Organisation and the United Kingdom" Potchefstroom Electronic Law Journal 19(1): 1-28

Foner PS (1986) A Short History of the International Workers Holiday 1886-1986 (New York)

Gostner K \& Joffe A (1998) “Negotiating the future: Labour's role in NEDLAC” Law, Democracy \& Development: 131-151

Hepple B (2001) “Equality and empowerment for decent work” International LR 140(1): 5-18 


\section{TENZA}

Kok A (2008) "The Promotion of Equality and Prevention of Unfair Discrimination Act 4 of 2000: Court-driven or legislature-driven societal transformation?" Stellenbosch LR 19: 122-142

Parsons R (2001) "Steps towards social dialogue and the development of NEDLAC in a democratic South Africa 1979-2001" South African J of Economic History 16: 139-171

Parsons R (2007) "The emergence of institutionalised social dialogue in South Africa" South African J of Economics 75(1): 1-21

Smith A (2014) "Addressing South Africa's labour market challenges - A future role for social dialogue and tripartism?" The Dispute Resolution Digest: 81

Theron J (2014) "Decent work and the crisis of labour law in South Africa" Industrial Law J 35: $1829-1850$

Theron J (2005) "Intermediary or employer? Labour brokers and the triangular employment relationship" Industrial Law J 26: 618-649

Van Niekerk A, Smit E, Christianson MA, McGregor M \& Van Niekerk BPS (2015)Law@work (LexisNexis, South Africa)

Webster E (1995) "NEDLAC: Corporatism of a special type?" South African Labour Bulletin 19(2): 33

\section{Websites}

Decent Work Agenda of the ILO (accessed 18 Nov 2017) available at http://www.ilo.org/global/ about-the-ilo/decent-work-agenda/lang-en/index.htm

https://www.buildon.org/global-education-crisis-facts/?gclid=Cj0KCQjw95vPBRDVARIsAKvP d3LUbOcUfpwsRWJK-wXnd5rQXN62rYHoELR3pd7obrZnnKTGoCwBsJIaAmJ1EALw $w c B$

Ensor L (accessed 19 Oct 2017) "Minimum wage to come into force in May 2018", available at http://www.heraldlive.co.za/news/2017/02/08/minimum-wage-come-force-may-2018/

Godaan S (accessed 19 Oct 2017) "The state of the union? Attitudes to South African trade unions" (HSRC) available at http://www.hsrc.ac.za/en/review/hsrc-review-march-2013/thestate-of-the-union

http://www.sahistory.org.za/dated-event/1-may-international-workers-day (accessed 19 Oct 2017)

ILO 1999 (accessed 11 Oct 2017) http://www.ilo.org

ILO 2010 (accessed 11 Oct 2017) http://www.ilo.org

Memorandum on Objects of Employment Equity Amendment Bill 2012 (accessed 20 Oct 2017) available at $h t t p: / / w w w . g o v . z a / s i t e s / w w w . g o v . z a / f i l e s / B 31 B-2012 \_17 O c t 2013 . p d f$

National Minimum Wage Report (accessed 19 Oct 2017) available at http://www.treasury.gov.za/ publications/other/NMW\%20Report\%20Draft\%20CoP\%20FINAL.PDF

\section{Cases}

Louw v Golden Arrow Bus Services (Pty) Ltd (2000) 21 ILJ 188 (LC)

Mangena v Fila South Africa (Pty) Ltd (2010) 31 ILJ 660 (LC) 
People's Union for Democratic Rights v Union of India 1983 (1) SCR 546

$S v$ Meyer 1981 (4) SA 604 (A)

SANDU v Minister of Defence (1999) 4 SA 469 (CC)

\section{Legislation}

Basic Conditions of Employment Act 75 of 1997

Compensation for Occupational Injuries and Diseases Act 130 of 1993

Constitution of South Africa, 1996

Employment Equity Act 55 of 1998

Employment Equity Amendment Act 47 of 2013

Employment Equity Amendment Bill [B31B of 2012]

Internal Security Act 74 of 1982

Labour Relations Act 66 of 1995

Labour Relations Amendment Act 6 of 2014

Mine Health and Safety Act 29 of 1996

National Economic Development and Labour Council Act 35 of 1994

Occupational Health and Safety Act 85 of 1993

Public Safety Act 3 of 1953

Skills Development Act 97 of 1998

Suppression of Communism Act of 1950 